\title{
Preparasi periodontal pada pembuatan gigitiruan Periodontal preparation in denture making
}

\author{
${ }^{1}$ Sri Lelyati C. Masulili, ${ }^{1}$ Yulianti Kemal, ${ }^{2}$ Chaidar Masulili \\ ${ }^{1}$ Departemen Periodonsia \\ ${ }^{2}$ Departemen Prostodonsia \\ Fakultas Kedokteran Gigi, Universitas Indonesia \\ Jakarta, Indonesia
}

\begin{abstract}
Periodontal health of prosthodontic patients should be maintained to support the succeed of prosthodontic treatment. The purpose of periodontal preparation i.e. examination and diagnose of periodontal disease/condition and its treatment; the need of preprosthetic periodontal surgery is to support the succeed of prosthodontic treatment. It's included the quality, quantity, and topography of periodontium and alveolar mucosa, occlusal traumatism, tooth mobility, and the need of mucogingival surgery, crown lengthening, ridge augmentation etc. The prosthetic procedures should be done with fully aware of the periodontal health i.e. the roughness of denture surface, the place and condition of marginal restoration, contact point, and improper the contour of restoration. It is concluded that to support the succeed of prosthodontic treatment, periodontal preparation should be planned and carried out before prosthodontic procedures.
\end{abstract}

Key words: etiology of periodontal disease, periodontal treatment, preprosthetic periodontal surgery

\begin{abstract}
ABSTRAK
Preparasi periodontal adalah perawatan periodontal yang harus dilakukan sebelum serta saat pembuatan gigitiruan, meliputi melakukan, diagnosis, dan perawatan periodontal, serta bedah preprostetik jika diperlukan. Preparasi periodontal ditujukan untuk menunjang keberhasilan pemakaian gigitiruan. Untuk menunjang keberhasilan pemakaian gigitiruan, antara lain perlu diperhatikan sisa gigi, kualitas dan kuantitas jaringan periodontal, topografi periodontal, trauma oklusi, kegoyangan gigi, fungsi pengunyahan, estetik, serta mempertimbangkan perlunya perawatan bedah preprostetik seperti bedah mukogingiva, pemanjangan mahkota akar, ridge augmentation. Pada pembuatan gigitiruan, harus diperhatikan bahwa tidak mengakibatkan kerusakan jaringan periodontal, seperti permukaan gigitiruan yang kasar, kondisi dan penempatan tepi restorasi, titik kontak, serta kontur gigi yang tidak baik. Dari pembahasan, disimpulkan bahwa untuk menunjang keberhasilan pembuatan gigitiruan maka perlu diperhatikan dan bila mungkin dilakukan preparasi periodontal sebelum pemasangan gigitiruan.
\end{abstract}

Kata kunci: etiologi penyakit periodontal, perawatan periodontal, bedah periodontal preprostetik

Koresponden: Sri Lelyati, Departemen Periodonsia Fakultas Kedokteran Gigi Universitas Indonesia, Jl. Salemba Raya No. 4, Jakarta, Indonesia. E-mail: srilelyati@yahoo.com

\section{PENDAHULUAN}

Preparasi periodontal adalah perawatan jaringan periodontal yang harus diperhatikan dan dilakukan sebelum serta saat pembuatan gigitiruan. ${ }^{1}$ Hal-hal yang diperhatikan adalah faktor etiologi penyakit periodontal, mempertimbangkan perawatan nonbedah periodontal, dan bedah preprostetik jika diperlukan.

Keberhasilan pemakaian gigitiruan sangat ditunjang oleh kesehatan jaringan periodontal. Oleh karena itu, perlu dipertimbangkan adanya sisa gigi, kualitas dan kuantitas jaringan periodontal,topografi periodontal, trauma oklusi, kegoyangan gigi, serta mempertimbangkan perawatan bedah preprostetik seperti pemanjangan mahkota akar/soft tissue graft/ ridge augmentation, juga fungsi pengunyahan serta estetik. $^{1-5}$ Pada gigitiruannya harus diperhatikan bahwa pembuatannya tidak menyebabkan kerusakan jaringan periodontal,seperti mengganggu kebersihan mulut akibat adanya gigitiruan yang permukaannya kasar, tekanan oklusal yang tidak merata, serta tepi restorasi atau titik kontak dan kontur gigi yang tidak baik. $^{1}$

Penulisan artikel ini dimaksudkan agar para sejawat memahami pentingnya memperhatikan kondisi periodontal untuk menunjang keberhasilan gigitiruan sebelum dan selama pemakaiannya.

\section{TINJAUAN PUSTAKA}

\section{Etiologi kelainan periodontal yang dihubungkan dengan gigitiruan}

Beberapa penelitian epidemiologis menunjuk bahwa plak gigi merupakan suatu faktor penting dalam etiologi periodontitis. Kontrol plak yang baik dapat menyembuhkan gingivitis dan periodontitis. ${ }^{6}$ Pemasangan gigitiruan lepasan mempengaruhi kondisi ekologi rongga mulut sehingga meningkatkan pembentukan plak pada sisa gigi yang ada. ${ }^{7}$ 
Restorasi sementara umumnya digunakan setelah preparasi gigi hingga pemasangan restorasi tetapnya. ${ }^{8}$ Tujuan pemasangan restorasi sementara tersebut adalah untuk memelihara gigi penyangga, fungsi, integritas pulpa,dan kesehatan periodontalnya. ${ }^{8}$ Akan tetapi seringkali pemasangan restorasi sementara menyebabkan kerusakan periodontal seperti terjadi inflamasi gingiva,retensi plak serta impaksi maupun retensi makanan.

Umumnya, gigi yang telah dicabut dibuatkan gigitiruan lepasan.Beberapa kegagalan dapat terjadi pada gigitiruan lepasan karena terjadi fraktur pada saat berfungsi,adanya retensi plak atau estetika yang tidak adekuat. ${ }^{9}$ Faktor yang penting diperhatikan pada gigitiruan lepasan adalah distribusi tekanan, yaitu dengan menggunakan konektor mayor dan minor serta multiple rests atau guiding planes. ${ }^{9}$

Penelitian-penelitian klinis telah menunjukkan bahwa adanya periodontal dapat dikurangi.Hal yang harus diperhatikan adalah kondisi periodontal yang mendukung gigi penyangga, disain yang tepat dan kebersihan mulut yang baik. ${ }^{9}$

Beberapa peneliti telah menunjukkan pengaruh gigitiruan lepasan dengan basis akrilik resin terhadap kesehatan gingiva. ${ }^{10}$ Peneliti-peneliti tersebut antara lain melaporkan bahwa setelah 21 hari pemakaian gigitiruan lepasan, terjadi peningkatan rasa kurang nyaman pada gingiva, dan juga terjadi pendalaman poket periodontal. ${ }^{10}$

Kegoyangan gigi penyangga dapat dipengaruhi oleh berbagai macam faktor seperti lokasi rest, kontur serta kekakuan dari konektor-konektor,dan ekstensi dari gigitiruan sebagian. ${ }^{10}$ Umumnya, peningkatan kegoyangan gigi penyangga terjadi karena pengaruh ekstensi distal dari gigitiruan lepasan. ${ }^{10}$ Oleh karena itu, pengguna gigitiruan sebagian lepasan perlu melakukan kontrol periodik periodontal.

Ada tiga area kritis yang harus diatur untuk dapat menghasilkan respons biologik yang baik dari suatu restorasi,misalnya ketepatan tepi restorasi yang baik,kontur mahkota serta permukaan restorasi yang baik agar dapat memelihara kesehatan dan posisi jaringan gingiva. ${ }^{11}$ Hal-hal tersebut terutama akan memudahkan pembersihan daerah periodontal yang menunjang kesehatan jaringan periodontal.

\section{Preparasi periodontal sebelum pembuatan gigitiruan}

Preparasi periodontal sebelum tahap pembuatan gigitiruan terdiri dari 2 tahap. ${ }^{1,3-5}$ Pertama adalah perawatan non-bedah periodontal yang meliputi kontrol penyakit periodontal yang ada,dapat berupa perawatan emerjensi, pencabutan gigi yang tidak dapat dirawat, instruksi kebersihan mulut, skeling dan penghalusan akar,evaluasi ulang,juga perawatan bedah periodontal untuk terapi poket, serta terapi ortodonsi bila diperlukan.Kedua, bedah periodontal preprostetik,berupa perbaikan masalah mukogingiva, pemeliharaan lingir sesudah ekstraksi, prosedur pemanjangan mahkota gigi, dan rekonstruksi tulang alveolar. Prosedur bedah ini hanya dilakukan bila diperlukan dan sesuai indikasinya, selain itu bila peradangan jaringan periodontal sudah dikontrol sebelumnya.

Bedah periodontal yang dilakukan sebelum pembuatan gigitiruan, pada umumnya merupakan periodontal plastic dan bedah rekonstruksi. Disebut sebagai periodontal plastic surgery karena sifatnya yang membentukjaringan, dan disebutreconstructive surgery karena dilakukan untuk mengganti bagian yang rusak. Kedua prosedur bedah sering dibutuhkan dan dilakukan pada saat yang sama,sehingga disebut sebagai periodontal plastic and reconstructive surgery. ${ }^{2}$ Tindakan bedah periodontal ini juga sering dilakukan dengan tujuan estetik, beberapa ahli menyebutnya sebagai periodontal plastic and esthetic surgery ${ }^{1}$ atau cosmetic and reconstructive periodontal surgery. ${ }^{3}$

Beberapa tindakan bedah yang umum dilakukan sebelum pembuatan gigitiruan,yaitu prosedur bedah untuk perbaikan mukogingiva atau mucogingival surgery,penanganan lingir alveolar sesudah ekstraksi, prosedur pemanjangan mahkota gigi, rekonstruksi tulang alveolar, dan rekonstruksi papila.

\section{Bedah periodontal untuk perbaikan mukogingiva}

Kualitas jaringan lunak di sekitar gigitiruan atau restorasi tergantung dari imobilitas jaringan,gingiva yang berkeratin cukup panjang dan lebar, warnanya sesuai dengan jaringan di sekitarnya, dan tidak ada peradangan. Kualitas jaringan lunak dipengaruhi oleh biotipe gingiva yang bersifat genetik, jarak waktu pencabutan gigi, serta peradangan jaringan periodontal, tindakan bedah, dan prosedur graft sebelumnya.Umumnya prosedurbedah mukogingiva dilakukan dengan tujuan a) Untuk meningkatkan kualitas mukosa yang tipis, mobil, tidak berkeratin, menjadi lebih berkeratin danimobil,b) mendalamkan vestibulum, sehingga memudahkan pemeliharaan kebersihan mulut,c) meningkatkan ketebalan jaringan lunak di sekitar gigitiruan sehingga memperbaiki biotipe gingiva yang tipis menjadi jaringan yang lebih stabil, dan estetis, d) eliminasi poket yang melebihi batas mukogingiva, e) eliminasi tarikan otot dan frenulum,serta melindungi permukaan akar yang terbuka. ${ }^{3-5}$

Prosedur bedah mukogingiva dibagi menjadi beberapa kategori, yaitu free soft tissue graft, soft 
tissue pedicle graft, kombinasi free soft tissue dan soft tissue pedicle graft, frenektomi dan rekonstruksi papila ginigva. ${ }^{1-4}$ Free soft tissue graft dilakukan bila donor jaringan lunak diambil dari tempat yang berbeda dengan area yang akan diterapi, sedangkan soft tissue pedicle graft dilakukan bila donor diambil dari area yang akan diterapi.Yang termasuk free soft tissue graft adalah free gingival graft/graft free gingiva/graft berepitel dan subepithel connective tissue graft. Yang termasuk soft tissue pedicle graft adalah coronally positionedflap, apically positioned flap, laterally positioned flap, double papillae positioned flap, semilunar flap, transpositional flap, dan connective tissue pedicle graft.

Indikasi free gingival graft adalah untuk meningkatkan volume jaringan lunak di sekitar gigitiruan, meningkatkan gingiva yang berkeratin, mencegah perlekatan kembali pada frenulum yang tinggi,menutup akar yang terbuka serta mendalamkan vestibulum. Prinsip terapi ini adalah insisi pada gingiva atau batas mukogingiva daerah operasi, kemudian dilakukan split thickness flap/partial thickness flap sehingga tulang masih ditutupi oleh selapis jaringan ikat. Setelah itu, flep ditarik ke apikal, dan dijahit. Pada terapi ini, diperlukan graft free gingiva dengan ketebalan $2 \mathrm{~mm}$ diambil dari palatum regio antara gigi premolar pertama dan molar pertama, daerah tuber atau dari regio tidak bergigi,sedangkan panjang dan lebarnya disesuaikan dengan kebutuhan. Graft free gingiva kemudian dijahitkan menutupi jaringan ikat yang terbuka. ${ }^{1,4}$ Teknik ini pertama kali ditemukan oleh Miller. ${ }^{3}$

Indikasi subepithel connective tissue graft terutama untuk terapi resesi gingiva dengan gingiva yang tipis. Tujuannya adalah menambah ketebalan gingiva dengan graft jaringan ikat, dan umumnya kemudian dilakukan coronally flap untuk menutupi resesi gingiva. ${ }^{4}$ Prinsip terapi ini seperti pada free gingival graft, yaitu pada daerah yang akan diterapi dilakukan flap dengan teknik split. Donor berupa graft jaringan ikat yang diambil dengan teknik trap door. Untuk menambah ketebalan gingiva pada daerah resipient, maka graft disisipkan diantara flap gingiva yang telah disiapkan dengan teknik split., ${ }^{3,4}$ Teknik ini dikemukakan Langer dan Langer's. ${ }^{3}$ Pembuatan restorasi setelah tindakan ini,dianjurkan 2 bulan setelah tindakan grafting. ${ }^{1}$

Coronally positioned flap dilakukan untuk menutup resesi gingiva terutama karena alasan estetis, selain itu untuk terapi rasa ngilu. Prinsip dari terapi ini adalah dilakukan full thickness flap dengan dua insisi vertikal, kemudian pada bagian apikal diundermind untuk melepaskan flap dari periosteum, sehingga flap dapat ditarik ke korona $1 \mathrm{~mm}$ di atas
CEJ tanpa tegangan.Pada posisi tersebut,flap dijahit dengan teknik sling mengelilingi gigi. ${ }^{1,2}$

Apically positioned flap dilakukan untuk menambah area perlekatan gingiva, mendalamkan vestibulum,dan mengurangi kedalaman poket. Pada perkembangannya, juga dilakukan pada prosedur crown lengthening yang membutuhkan reseksi tulang dan mempertahankan gingiva berkeratin. ${ }^{2}$ Prinsip terapinya adalah memindahkan flap lebih ke posisi sebelumnya, kemudian dilakukan penjahitan pada posisi tersebut.

Laterally positioned flap merupakan prosedur untuk menutup resesi gingiva. Pada prinsipnya, daerah resesi ditutup dengan gingiva dari flap yang berasal dari insisi vertikal dengan teknik split, yang kemudian diposisikan pada arah satu sisi. ${ }^{2}$

Doublepapillae positioned flap juga merupakan prosedur penutupan resesi gingiva dengan gingiva yang berasal dari papila gingiva di kiri kanannya yang telah dilakukan flap dengan insisi vertikal di kedua sisi dan teknik split. ${ }^{2}$

Semilunar flap dilakukan untuk menutup resesi gingiva sebesar 2-3 mm. Teknik ini dikemukakan oleh Tarnow. Prinsip terapi merupakan modifikasi teknik reposisi ke korona,tetapi tanpa insisi vertikal. Insisi semilunar dilakukan tidak sampai ke tulang di apikal tepi gingiva dan dibentuk mengikuti tepi gingiva. Setelah itu, dilakukan flap dengan teknik split, kemudian gingiva ditarik ke koronal menutupi resesi. $^{3}$

Transpositionalflap merupakan modifikasi dari laterally positioned flap, dan insisi flap diperpanjang oblique sepanjang permukaan akar yang terbuka. Dengan demikian dasar flap menjadi lebih luas, manipulasi lebih mudah, dan sumber darah yang mendukung penyembuhan lebih banyak. Teknik ini diperkenalkan oleh Bahat $\mathrm{dkk}^{3}$

Connective tissue pedicle flap/pediculated connective tissue graft (PCTG) dilakukan untuk augmentasi lingir pada regio estetik.Pada prinsipnya, daerah deformitas diperbaiki dengan mengisinya dengan graft jaringan ikat yang berasal dari bagian palatum daerah yang sama dengan melipatnya ke bagian bukal. ${ }^{2,3}$

Kombinasi free soft tissue graft dan teknik pedicle flap, umumnya dilakukan pada kondisi gingiva berkeratin tidak adekuat,atau gingiva terlalu tipis sehingga hanya dengan pedicle flap saja tidak akan didapatkan hasil yang sempurna. ${ }^{3,4}$ Mula-mula gingiva ditambah ketebalannya dengan graft jaringan ikat atau free gingiva. Gingiva yang sudah bertambah kemudian dilakukan pedicle flap yaitu coronally, laterally atau double papillae untuk menutup resesi gingiva. Prosedur operasi dapat dilakukan langsung 
dalam satu kali operasi atau bertahap. Menurut para peneliti, dengan kombinasi teknik ini, keberhasilan terapi dapat meningkat sampai lebih $90 \% .^{3-5}$

Frenektomi dilakukan bila perlekatan frenulum terlalu tinggi,sehingga dapat mengganggu perawatan ortodontik, penyembuhan pada terapi poket karena dinding poket berdekatan dengan perlekatan frenulum, dan penyembuhan pada operasi bedah mukogingiva. Pada prinsipnya, frenulum dijepit dengan hemostat, kemudian dilakukan insisi di atas dan di bawah hemostat, lalu frenulum dilepaskan. Dibuat insisi horisontal, kemudian jaringan fibrous yang melekat pada tulang dilepaskan dan mukosa labial dijahitkan ke periosteum. ${ }^{1-3}$

Rekonstruksi papila untuk tujuan estetis, yaitu rekonstruksi papila di daerah interproksimal. Umumnya, merupakan kombinasi prosedur operasi insisi sulkular, dan grafting jaringan ikat, kemudian flap diposisikan ke arah korona.Pemakaian gigitiruan sementara yang sesuai dengan bentuk papila yang diinginkan membantu terbentuknya papil pada waktu penyembuhan sesuai dengan yang diharapkan. ${ }^{3}$

\section{Pemeliharaan lingir alveolar sesudah ekstraksi}

Seringkali pemeliharaan lingir diperlukan pasca pencabutan gigi untuk mendukung keberhasilan perawatan prostodonsi. Adapun tindakan tersebut diperlukan untuk menjaga dan memperbaiki fungsi estetis; memperbaiki dan memelihara soket dan lingir, meningkatkan kualitas tulang, memperbaiki penempatan implan,dan memperbaiki disain pontik. Ada macam-macam bahan yang dapat digunakan, antara lain 1) graft jaringan ikat menutup soket dikombinasi dengan demineralized freeze dried bone allograft (DFDBA) di dalam soket, 2) graft free gingiva; 3) kombinasi graft tulang Bio Oss di dalam soket dengan Bio $\mathrm{Col}$ atau bahan hemostatik yang dapat resorbsi, 4) guided bone regeneration dengan menggunakan membran yang resorbsi maupun yang tidak resorbsi. Bila kerusakan tulang besar, dapat digunakan kombinasi dengan bahan graft tulang di dalam soket;5) aloderm atau cellular dermal graft, 6) penggunaan imidiat denture pasca pencabutan dapat mempertahankan gingiva di daerah interproksimal dan subgingiva, 7) pemasangan implan langsung sesudah pencabutan, dikombinasi dengan bahan graft tulang DFDBA dan gigitiruan sementara, mempertahankan kontur gingiva,dan 8) penggunaan gigitiruan jembatan sementara segera sesudah pencabutan dapat mempertahankan papila gingiva.

\section{Crown lengthening}

Pemanjangan mahkota gigi umumnya dilakukan sebelum pembuatan restorasi gigi, yaitu bila ada karies pada atau di bawah marginal gingiva, gigi fraktur di bawah marginal gingiva dengan sisa jaringan periodontal yang masih adekuat, gigi dengan abrasi oklusal, gigi dengan ruang interoklusal yang terbatas, terlambatnya erupsi pasif sehingga marginal gingiva lebih ke arah korona daripada CEJ; jarak servikoinsisal gigi terlalu pendek sehingga retensi tidak cukup untuk pembuatan mahkota,tujuan estetis, misalnya pada kasus gigi anterior dengan kontur gingivanya yang tidak harmonis. ${ }^{2}$ Kontra indikasi dilakukannya pemanjangan akar gigi adalah bila perbandingan mahkota akar tidak adekuat, karies atau fraktur akar yang tidak dapat direstorasi,estetis kurang baik,keberhasilan diragukan, gigi tidak dalam lengkung gigi yang baik,kerusakan periodontal lanjut dengan prognosis buruk, ruang untuk pembuatan restorasi tidak cukup, atau pada kondisi yang sulit untuk dirawat dan dipertahankan. ${ }^{3}$

Sebelum prosedur bedah, dilakukan evaluasi klinis terhadap kesehatan gingiva,kedalaman sulkus, puncak tulang alveolar,biological width,keterlibatan pulpa, tepi apikal fraktur gigi, lokasi furkasi, ruang mesial, distal, dan oklusal, dan antisipasi letak tepi restorasi. Analisis gambaran radiologis dilakukan untuk menentukan tinggi tulang alveolar,tepi apikal fraktur atau karies, keterlibatan pulpa, panjang dan bentuk akar, kesehatan dan posisi furkasi, panjang akar, perbandingan mahkota akar sebelum dan perkiraan sesudah tindakan bedah. ${ }^{3}$

Pada prinsipnya,sesuai dengan analisis sejumlah ahli dikatakan bahwa untuk dapat mempertahankan kesehatan jaringan periodontal pasca bedah pemanjangan akar gigi,maka biological width harus dipertahankan sekitar $2 \mathrm{~mm}$. Dengan perhitungan bahwa jika kedalaman sulkus $1 \mathrm{~mm}$,maka jarak tepi gingiva ke puncak alveolar harus dipertahankan sekitar $3 \mathrm{~mm}$. Dasar perhitungan ini digunakan untuk menentukan apakah prosedur pemanjangan akar gigi perlu disertai ostektomi dan osteoplasti atau tidak.Bila reseksi tulang tidak diperlukan,maka cukup dilakukan gingivektomi atau gingivoplasti saja, akan tetapi bila reseksi tulang diperlukan maka harus dilakukan bedah flap apikal. ${ }^{3}$

\section{Rekonstruksi tulang alveolar}

Rekonstruksi tulang alveolar dilakukan bila ada defek tulang alveolar yang mengganggu estetik atau mengurangi retensi gigitiruan. Defek tulang alveolar diklasifikasikan sebagai Kelas 1,kerusakan tulang bukolingual tapi tinggi tulang apikokoronal normal, dan Kelas 2,kerusakan tulang apikokoronal lebar tulang bukolingual normal, serta Kelas 3, kerusakan tulang dalam arah bukolingual dan apikokoronal. $^{3}$ 


\section{PEMBAHASAN}

Ada beberapa macam cara augmentasi ridge seperti full thickness soft tissue grafts, prosedur pouch, ridge augmentation-improved technique, subepithelial connective tissue graft, interpositional onlay graft, dan ridge augmentation untuk gigitiruan implan.

Full thickness soft tissue grafts diperkenalkan oleh Meltzer, digunakan untuk memperbaiki estetik di daerah anterior dengan kerusakan tulang vertikal. Prinsip dari terapi ini adalah menghilangkan epitel di daerah resipien kemudian dilakukan pemotongan secara vertikal untuk menambah perdarahan, untuk selanjutnya graft free gingiva diletakkan menutupi daerah resipien dan kemudian dijahit. ${ }^{3}$

Prosedur pouch dilakukan untuk memperbaiki fungsi estetik karena ada kerusakan tulang horisontal di daerah labial. Pada prosedur ini, dilakukan insisi horisontal pada puncak tulang alveolar, kemudian dilakukan insisi split ke arah apikal dan lateral daerah deformitas. Graft jaringan ikat diselipkan di daerah deformitas dan dijahitkan ke mukosa labial. Bekas insisi kemudian dijahitkan.

Indikasi teknik ridge augmentation-improved terutama untuk kerusakan tulang horisontal. Prinsip terapi adalah melakukan insisi horisontal di daerah palatum 5-10 mm dari puncak tulang alveolar. Di daerahpalatumdilakukaninsisi split,mulai dari crest tulang alveolar sampai daerah deformitas di bagian bukal, kemudian flap dibuka secara full thickness ke apikal. Daerah deformitas kemudian diisi dengan bahan hidroksiapatitatau alograf yang tak teresorbsi, kemudian flap diposisikan kembali dan dijahit. ${ }^{3}$

Subepithelial connective tissue graft yang diperkenalkan oleh Langer dan Calagna, biasanya diindikasikan untuk semua bentuk kerusakan tulang alveolar. Prinsipnya adalah mengkombinasikan flap teknik split pada bagian bukal dan palatal, daerah flep kemudian diisi dengan graf jaringan ikat. ${ }^{2,3}$

Interpositional onlay graft dilakukan untuk kerusakan tulang kelas 3,yaitu arah bukolingual dan apikokoronal. Pada kondisi ini, kerusakan tulang besar sehingga seringkali dibutuhkan lebih dari satu graft. Graft pertama diselipkan di daerah bukal, graft kedua diletakkan di atasnya menutupi puncak tulang alveolar, kemudian satu sama lain dijahit, dan flap ditutup. Pada keadaan gigi kiri kanannya ada resesi gingiva, dapat ditambahkan graft ketiga untuk menutup permukaan akar. ${ }^{3}$

Ridge augmentation untuk gigitiruan dukungan implan. Gold standard untuk rekonstruksi tulang alveolar pada gigitiruan dukungan implan adalah graft tulang yang berasal dari orang itu sendiri. Walaupun demikian, bahan alogenik dan aloplastik masih sering digunakan, terutama pada kerusakan tulang yang tidak terlalu besar. Sisi donor ekstra oral yang sering digunakan adalah tulang iliaka, dan kalvaria; sedangkan intra oral adalah dagu, lateral ramus mandibula, prosesus koronoideus, dan tuber maksilaris. Teknik yang digunakan adalah veener graft untuk kerusakan tulang horisontal, onlay graft untuk kerusakan tulang vertikal, split ridge atau sandwich technique untuk kerusakan tulang horisontal dan vertikal, " $J$ " atau saddle graft untuk kerusakan tulang horisontal dan vertikal.

Berbagai macam tindakan bedah periodontal preprostetiktersebut diatas dapat dilakukan sebelum pembuatan gigitiruan sesuai indikasinya dengan pertimbangan akan memperbaiki serta meningkatkan kesehatan jaringan periodontal.

Dari pembahasan,disimpulkan bahwa preparasi periodontal sebelum pembuatan gigitiruan, yaitu perawatan non bedah periodontal yang meliputi kontrol terhadap penyakit periodontal yang ada, serta bedah periodontal preprostetik yang dilakukan bila perlu dan disesuaikan menurut indikasinya. Keberhasilan pemakaian gigitiruan sangat ditunjang oleh kesehatan jaringan periodontal.Oleh karena itu, perlu diperhatikan faktor-faktor yang berpengaruh sebelum dan selama pemakaian gigitiruan, terutama terhadap kebersihan dan kerusakan pada jaringan periodontal.

\section{DAFTAR PUSTAKA}

1. Melnick P. Preparation of the periodontium for restorative dentistry. In: Newman MG, Takei HH, Klokkevold PR, Carranza FA, editors. Carranza's clinical periodontology. $10^{\text {th }}$ Ed. St Louis: Saunders Elsevier; 2006.p.1039-49.

2. Glover ME. Periodontal plastic and reconstructive surgery. In: Rose LF, Mealey BL, Genco RJ, Cohen DW, editors. Periodontics: medicine, surgery, and implants. St Louis: Elsevier Mosby; 2004.p.405-87.

3. Cohen ES. Atlas of Cosmetic and Reconstructive Periodontal Surgery. $3^{\text {rd }}$ ed. Connecticut: People's Medical Publishing House, 2009:249-258, 275-327.

4. Saha S. Mucogingival grafting procedures. In: Bateman G, Saha S, Chapple I, editors. Contemporary periodontal surgery: an ilustrated guide to the art behind the science. Warsawa: Quintessence Pub Co,; 2007.p.143-58.

5. Butterworth C.Soft tissue surgery around dental implants. In:Bateman G, Saha S, Chapple I, editors. Contemporary periodontal surgery: An ilustrated guide to the art behind the science. Warsawa: Quintessence Pub Co,; 2007.p.167-84. 
6. Bergman B. Periodontal reactions related to removable partial denture: literature reviews. J Prosthet Dent 1987; 58(4):454-7.

7. El-Ghmamrawy E. Quantitative changes in dental plaque formation related to removable partial dentures. J Oral Rehabil 1976; 3:115-20.

8. Bral M. Periodontal considerations for provisional restorations. Dent Clin North Am 1989; 33:457-77.

9. Chaiyabutr Y, Brudvik JS. Removable partial denture design using milled abutment surfaces and minimal soft tissue coverage for periodontally compromised teeth: A clinical report. J Prosthet Dent 2008; 99:263-6.

10. Qudah SA, Nassrawin N. Effect of removable partial denture on periodontal health. JRMS 2004; $11(2): 17-9$.

11. Spear FM, Cooney JP. Restorative interrelationships. In: Newman MG, Takei HH, Klokkevold PR, Carranza FA, editors. Carranza's clinical periodontology. $10^{\text {th }}$ Ed. St Louis: Saunders Elsevier; 2006.p.1050-69. 